\title{
Inhaltsverzeichnis / Содержание
}

W. Hedeler: Einleitung $\ldots \ldots \ldots \ldots \ldots \ldots \ldots \ldots \ldots \ldots \ldots \ldots \ldots \ldots$ VII

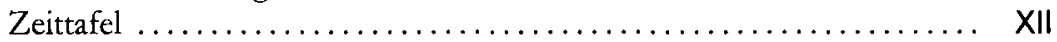

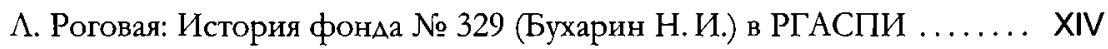

\section{Bibliographie / Библиография}

Reden, Beiträge und Monographien /

Аоклады, статьи и монографии ....................... 3

Briefe von N. I. Bucharin /

Письма Н. И. Бухарина ....................... 268

Briefe an N. I. Bucharin /

Письма в адрес Н. И. Бухарина ..................... 322

Werkausgaben und Publikationen über Leben und Werk von Bucharin 1988-2005/

Избранные труды и публикации о жизни и творчестве Бухарина

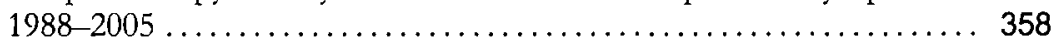

Verzeichnis des Bucharin-Bestandes im RGASPI /

Содержание описей фонда Н. И. Бухарина в РГАСПИ ....... 405

Bucharins Karikaturen und Bucharin in der Karikatur I

Карикатуры Бухарина и Бухарин в карикатурах

Verzeichnis der Karikaturen /

Указатель карикатур ............................... 417

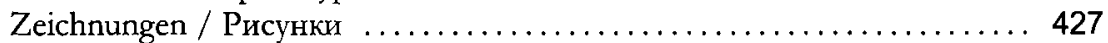

А. Ватлин: Бухарин в рисунках своих друзей и недругов .......... 447

\section{Verzeichnisse / Указатели}

Abkürzungsverzeichnis /

Указатель сокрашений

Verzeichnis der Presseorgane /

Список периодических изданий $\ldots \ldots \ldots \ldots \ldots \ldots \ldots \ldots \ldots \ldots . \ldots . \ldots \ldots 1$

Verzeichnis der Schriften ............................... 470

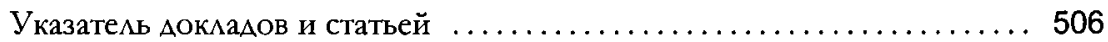

Namenverzeichnis /

Именной указатель ........................... 533 
